\title{
Influence of Continuous Gamma Irradiation on Morpho-agronomic Characteristics of Amaranthus caudatus in M1 and M2 Generations
}

\author{
Veer Singh Rawat ${ }^{1}$, Shyam Shanker Singh ${ }^{2, *}$, Mohd Rafi Wani , Ankita Singh ${ }^{2}$ \\ ${ }^{1}$ District Institute for Education and Training (DIET), New Tehri, India \\ ${ }^{2}$ Department of Forestry, Wildlife and Environmental Sciences, Guru Ghasidas University, Bilaspur, India
}

Email address:

singhss.ggu@gmail.com (S. S. Singh)

${ }^{*}$ Corresponding author

\section{To cite this article:}

Veer Singh Rawat, Shyam Shanker Singh, Mohd Rafi Wani, Ankita Singh. Influence of Continuous Gamma Irradiation on Morphoagronomic Characteristics of Amaranthus caudatus in M1 and M2 Generations. American Journal of Agriculture and Forestry. Vol. 5, No. 4, 2017, pp. 130-136. doi: 10.11648/j.ajaf.20170504.17

Received: May 28, 2017; Accepted: June 14, 2017; Published: July 24, 2017

\begin{abstract}
Amaranthus caudatus play an important role against hunger and malnutrition that occur due to low rain fall conditions, gaining a wide attention in food and medicinal industry. Being a versatile plant in terms of its nutritional value the improvement of this plant with reference to germination, growth and yield is still uncharacterized. Therefore the present investigation is carried out to determine the influence of gamma radiation in modifying germination, growth and yield attributes of Amaranthus caudatus. The air dried seeds were exposed to different gamma irradiation doses (10KR, 20KRC, 40KRC and 80KRC) using ${ }^{60} \mathrm{Co}$ source, sowing was carried out in a complete randomized block design, and the observations were taken upto M2 generation. The results showed that the influence of different doses of gamma irradiation on germination parameters was significant in M1 and M2 generations. The influence on the survival percentage was obtained in both M1 and M2 generation, and highest percentage of survival was recorded under 20KRC in both M1 and M2 generations. The average yield per plant in M1 and M2 generations were observed higher under 20KRC dose level of gamma irradiations. The gamma irradiation treatment showed significant enhancement in different growth parameters in both M1 and M2 generations. Also, it was observed that the growth and yield in M2 generation across all doses was better than M1 generation.
\end{abstract}

Keywords: Amaranthus caudatus, Gamma Irradiations, Growth, Yield, M1 and M2 Generation, Morpho-agronomic Characteristics

\section{Introduction}

Amaranthus caudatus (family Amaranthaceae) is underutilized pseudo cereal that can play an important role against hunger and malnutrition that occur due to low rainfall conditions. It is a broad-leafed non-grass plants that produce significant amounts of edible cereal like grains having an exceptional nutritive value. Amaranth is very versatile as a food ingredient and can diversify farming enterprise, as it can be expected to prevent food deficit and to feed the world [1]. Amaranthus caudatus grows rapidly and has a high tolerance to arid conditions and poor soils where traditional cereals cannot be grown. Amaranthus caudatus seeds with their phenomenal nutritional profile provide several important nutrients that are often difficult to incorporate into a restrictive diet. The seeds contain large amounts of dietary fiber, iron, and calcium. It also have high amounts of lysine, methionine and cysteine, combined with a fine balance of amino acids, making them an excellent source of high quality, balanced protein, which is more complete than the protein found in most grains. In addition to its outstanding nutritional value, amaranth is also very low in sodium and contains no saturated fat [2]. The increasing world population has raised concerns over food security. In order to feed the world, the projected target is to double food production by 2050. However, to fulfill these objective plants with better growth and yield should be preferred. So, from last few years new technologies have been developed to improve the 
growth and yield of agriculture crops. Across all the techniques, gamma rays induced crop improvement is one which has shown a possible gain in the germination, morphoagronomic traits of different agriculture crops within less time.

Gamma rays can cause multiple alterations in plant both morphologically and physiologically through direct and indirect interactions with an organism [3-4]. Gamma rays produce free radicals, which can damage various important compounds in plant cells and brings changes in morphology, growth, biochemical and physiological level [5-6]. Some of these include visible changes such as abnormal shape or appearance, reduced growth and reduced reproductive capacity [7-8], and physiological alterations such as accumulation of anthocyanin, expansion of root radial cells, induction of trichome formation, dilation of thylakoid membranes, change of photosynthesis, modulation of antioxidative system [9-13]. Several positive mutations have been created in agricultural crops by using gamma irradiations. Crops with improved characteristics have successfully been developed by mutagenic inductions [1415]. Considering the effects of radiation on plants, the present study was conducted to determine the effects of gamma irradiation on Amaranthus germination and some Morpho-agronomic characteristics and its yield in M1 and M2 generations.

\section{Material and Methods}

The air dried seeds were irradiated with different doses of gamma rays $(10 \mathrm{KR}, 20 \mathrm{KR}, 40 \mathrm{KR}$ and $60 \mathrm{KR})$ using a ${ }^{60} \mathrm{Co}$ gamma source with strength of $100 \mathrm{rad} / \mathrm{sec}$. The dose regime selection was based on the previous studies treatment on genus Albizia, Bauhinia and Robinia [16-17] where significant results on different germination and growth attributes were recorded under different gamma irradiation treatments.

Hundred seeds were treated for each dose. Each treatment was replicated four times with 25 seeds in each replicate and the whole experiment was arranged in a Randomized Block Design. Seeds without treatment were taken as control samples and the results of irradiated seeds were compared with these untreated seeds. The experimentation for germination early growth behaviour has been carried out in petridishes. Seeds were washed with distilled water and then shifted to petridishes. Whatmann filter paper No. 1 have been used in petridishes. For studying the detailed growth behaviour the seeds have been grown in the first week of May in field having well drained and pulverized soil and fairly leveled plot. In order to observe the transmission of the modifications in different morpho-agronomic characteristics induced by different gamma irradiation doses in Amaranthus caudatus, the experiment was carried upto M2 generation for which the seeds of M1 generation for each treatment were collected and sown in the field following the methodology as designed for M1 generation

Emergence of radicle upto $2 \mathrm{~mm}$ long has been treated as germinated seeds [18]. The germinated seeds were counted daily from the starting of the experiment upto the end of the experiment and then the germination percentage was calculated.

Germination energy index (GEI) was calculated from daily germination record. For germination energy index an appropriate record of newly germinated seeds were made and GEI was calculated by equation..(1)

$$
\text { GEI }=\frac{A_{1}+\left(A_{1}+A_{2}\right)+\left(A_{1}+A_{2}+A_{3}\right)+\left(A_{1}+A_{2}+A_{3}+\cdots \ldots \ldots . . . A_{n}\right) \times 100}{Y x N}
$$

Where $A_{1}, A_{2}, A_{3}, \ldots \ldots . A_{n}$ is the number of seeds newly germinated on $1,2,3 \ldots$ and $n^{\text {th }}$ days, respectively. $\mathrm{N}$ is the total number seeds used for the treatment, and $\mathrm{Y}$ represents the number of days for each observation.

For germination value $(\mathrm{GV})$ germination data were considered upto the day when germination became constant for three consecutive days (peak value). The same day was used as a reference point for computing the germination value and was calculated by equation (2) [19].

$$
G \cdot V .=M D G X P V
$$

Where MDG is mean daily germination and PV is the peak value.

Analysis of shoot length, root length, leaf length, average leaf area and average yield per plant were measured on the final day of experiment. Plants under different treatments of gamma rays and control set have been uprooted after 92 days of planting in M1 generation. For M2 generation, plants under different treatments have been uprooted after 105 days of planting. The relative growth rates of the plants were determined in terms of their fresh and dry weight. Dry weight was calculated by keeping the seedlings in an oven at $80^{\circ} \mathrm{C}$ for 24hours.

The data was subjected to analyses of variance (ANOVA) in a randomized block design. Treatment means were compared using the Duncan Multiple Range Test [20] at $(\mathrm{P} \leq 0.05)$ level of significance.

\section{Result}

The effect of different gamma irradiation doses on germination in M1 and M2 generation is given in Figure 1 to Figure 4. No more significant difference in germination percentage was recorded in treated groups in both M1 and M2 generation. However a significant variation in germination energy index was observed in treated experimental set of both M1 and M2 generation than the control. The maximum germination energy index $(100 \pm 1.24)$ was observed under $60 \mathrm{KRC}$ in $\mathrm{M} 1$ generation than the control $(95 \pm 2.22)$. However the overall germination energy index in M2 generation under all tested doses were better than M1 generation. The lower gamma irradiation upto 20KRC didn't show a significant variation in germination value than the control, in contrast the doses above $20 \mathrm{KRC}$ significantly reduced $(P \leq 0.05)$ the germination value than the control. 


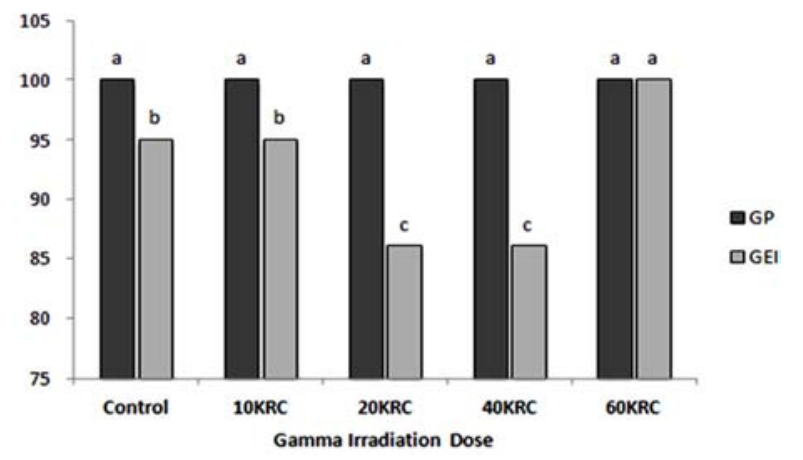

Figure 1. Amaranthus caudatus- Influence of continuous doses of gamma rays on germination percentage and germination energy index value (M1 generation).

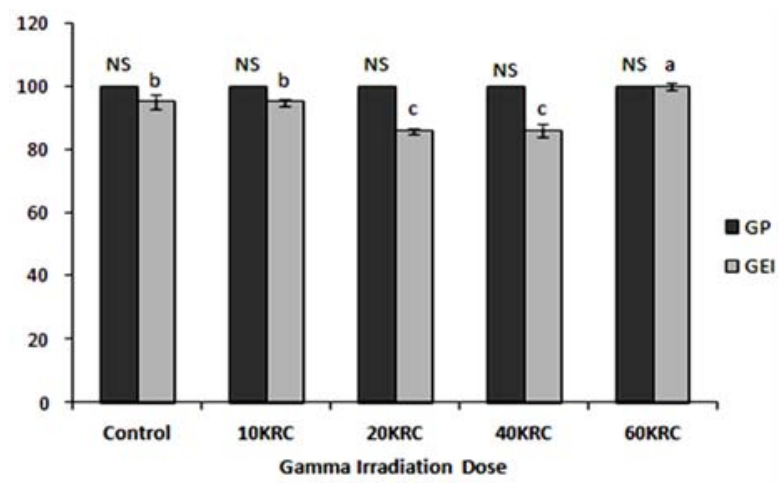

Figure 2. Amaranthus caudatus- Influence of continuous doses of gamma rays on germination percentage and germination energy index value (M2 generation).

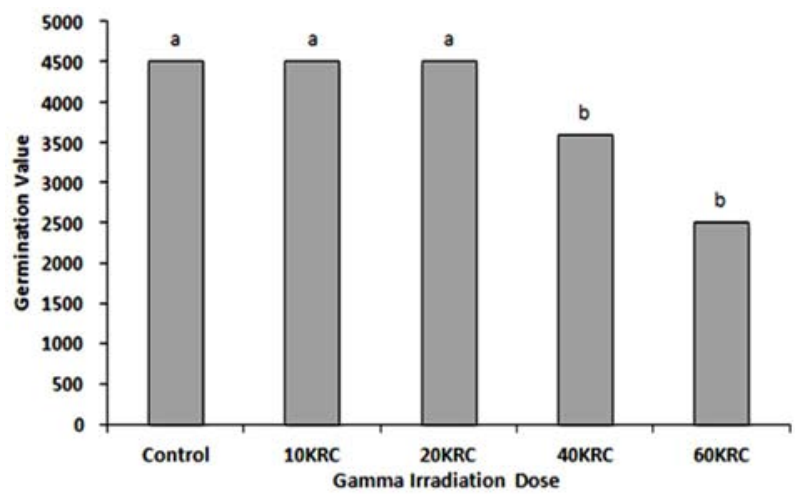

Figure 3. Amaranthus caudatus- Influence of continuous doses of gamma rays on germination value (M1 generation).

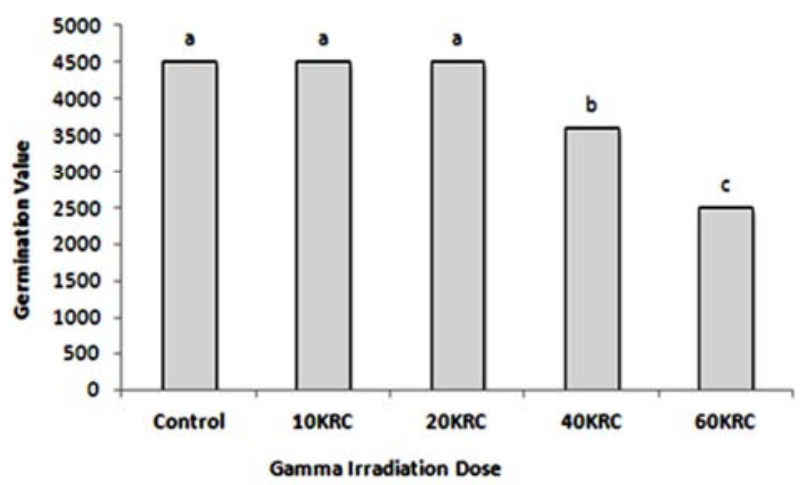

Figure 4. Amaranthus caudatus- Influence of continuous doses of gamma rays on germination value (M2 generation).

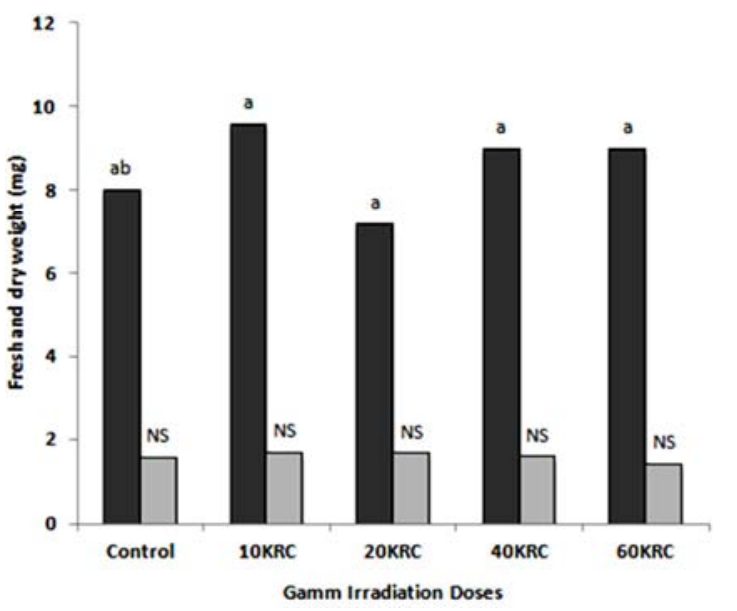

Figure 5. Amaranthus caudatus- - Fresh weight and dry weight of seedling as influenced by different continuous doses of gamma rays after 7 days (M1 generation).

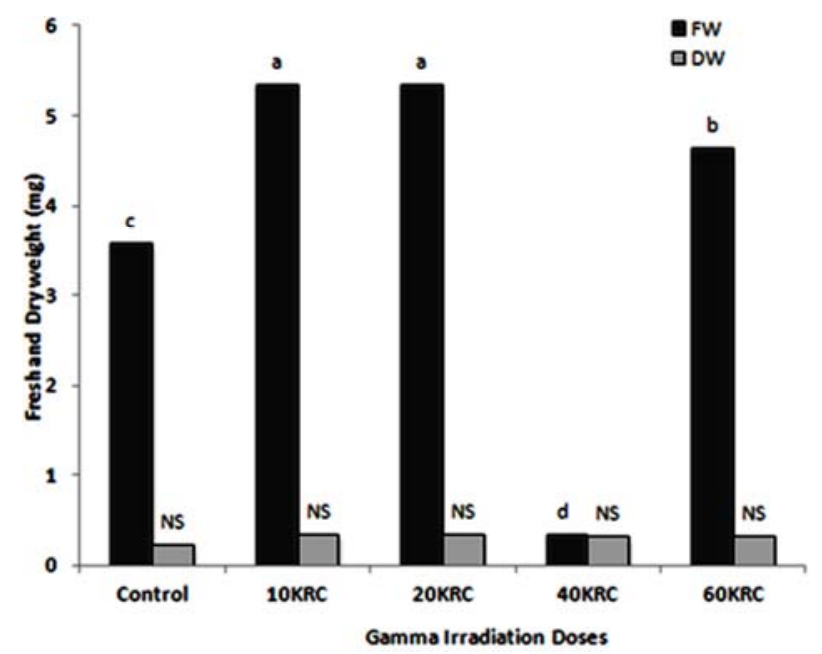

Figure 6. Amaranthus caudatus- - Fresh weight and dry weight of seedling as influenced by different continuous doses of gamma rays after 7 days (M2 generation).

Fresh weight of seedling in M1 and M2 generations were stimulated by different gamma irradiation doses (Figure 5 and Figure 6). The maximum enhancement of seedling fresh weight in M1 generation was recorded under the treatment of 10KRC (Figure 5) than the control, and in M2 generation the highest fresh weight was recorded for the seedlings treated with 20KRC (Figure 6) than the control. In contrast the dry weight of the seedling didn't show any significant difference across all the treated seedlings in both M1 and M2 generation.

Figure 7 and Figure 8 reveals that the survival percentage significantly increased $(P \leq 0.05)$ by gamma irradiation exposure in both M1 and M2 generations. In M1 generation the higher doses were found to be lethal and increased the mortality rate. However the lower doses stimulated the survival percentage in M1 generation and gaining its maximum value under 20KRC treatment. The highest mortality was recorded under $60 \mathrm{KRC}$ dose treatment. In contrast, the survival percentage in M2 were found higher under all treated doses than untreated plants. The 20KRC 
treatment showed maximum survival percentage, followed by $10 \mathrm{KRC}$ treatment (Figure $7 \& 8$ ).

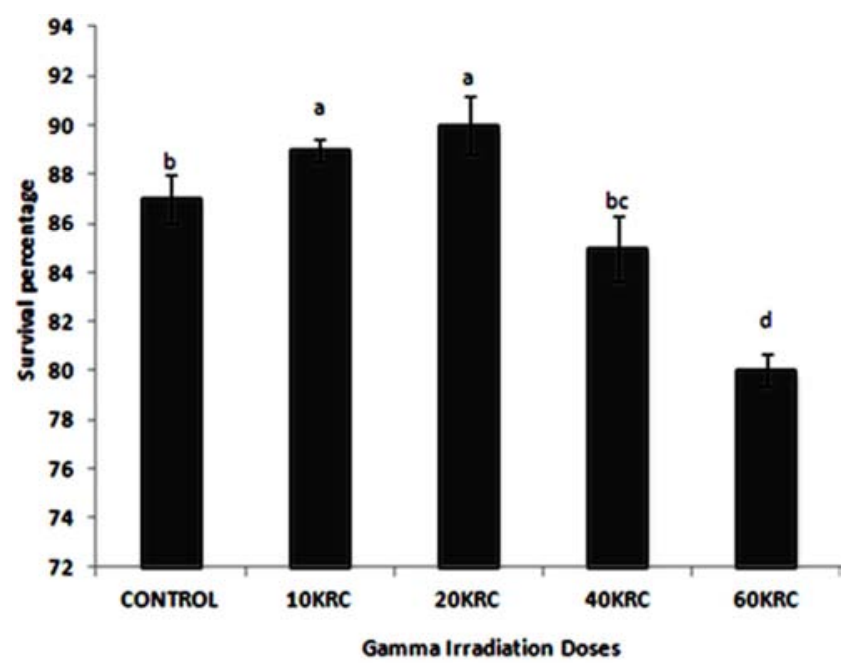

Figure 7. Amaranthus caudatus-Survival percentage as influenced continuous doses of gamma rays (M1 generation).

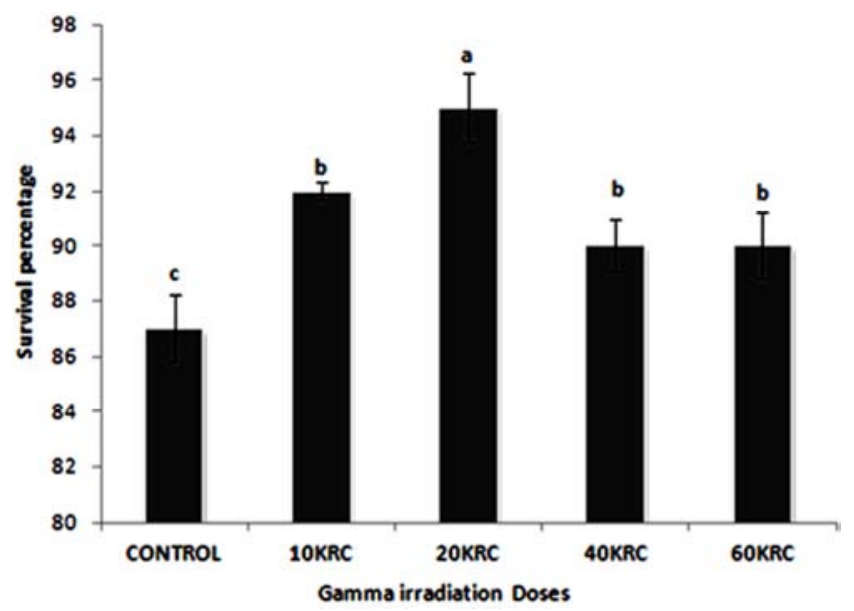

Figure 8. Amaranthus caudatus-Survival percentage by different as influenced by different continuous doses of gamma rays (M2 generation).
The average grain yield per plant (Figure 9\&10) has significantly increased $(P \leq 0.05)$ under $20 \mathrm{KRC}$ treatment, followed by $40 \mathrm{KRC}$ in comparision to control set. However the other doses don't show any significant difference than the control in M1 and M2 generation. The grain yield increased upto $66 \%$ in M2 generation in comparision to the control.

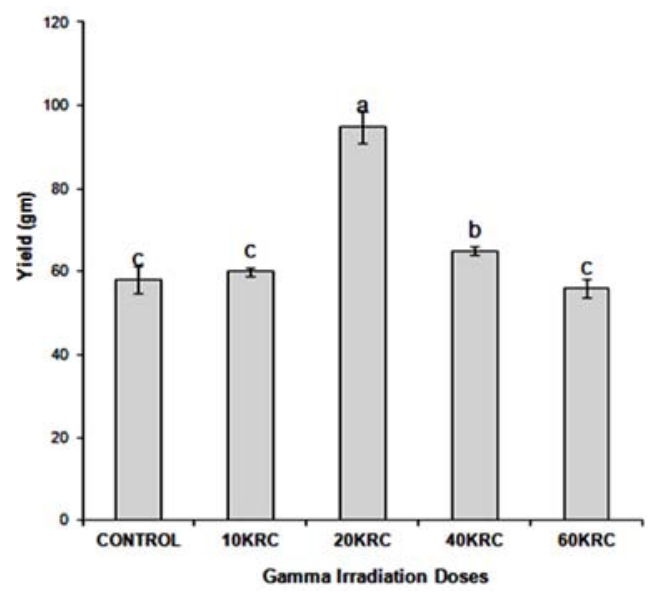

Figure 9. Amaranthus caudatus - Average yield per dose per plant as influenced by different continuous doses of gamma rays (M1 generation).

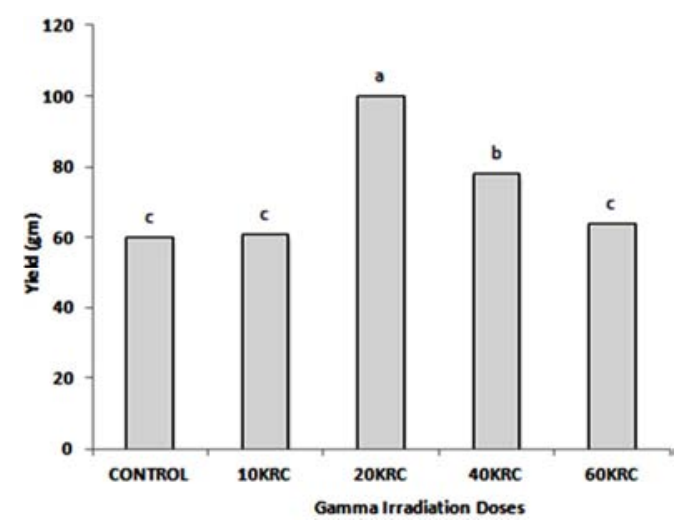

Figure 10. Amaranthus caudatus - Average yield per dose per plant as influenced by different continuous doses of gamma rays (M2 generation).

Table 1. Average root length, shoot length, number of leaves, leaf length and number of branches per plant in Amaranthus caudatus under influence of different doses of gamma radiations (M1 generation) after 92days of sowing.

\begin{tabular}{lllllll}
\hline Dose & $\begin{array}{l}\text { Average Root } \\
\text { Length/plant }(\mathbf{c m})\end{array}$ & $\begin{array}{l}\text { Average Shoot } \\
\text { Length/plant } \mathbf{( c m})\end{array}$ & $\begin{array}{l}\text { Average No. of } \\
\text { Leaves/plant }\end{array}$ & $\begin{array}{l}\text { Average Leaf Area } \\
\left.\text { /plant } \mathbf{( c m}^{2}\right)\end{array}$ & $\begin{array}{l}\text { Average Leaf } \\
\text { length /plant }\left(\mathbf{c m}^{2}\right)\end{array}$ & $\begin{array}{l}\text { Average number of } \\
\text { branches }\end{array}$ \\
\hline Control & $4.31 \pm 0.21^{\mathrm{a}}$ & $20.5 \pm 1.02^{\mathrm{ab}}$ & $12.4 \pm 0.44^{\mathrm{c}}$ & $1975.1 \pm 3.56^{\mathrm{b}}$ & $11.3 \pm 0.56^{\mathrm{a}}$ & $5.31 \pm 0.37^{\mathrm{b}}$ \\
$10 \mathrm{KRC}$ & $5.08 \pm 0.46^{\mathrm{a}}$ & $19.0 \pm 2.10^{\mathrm{b}}$ & $12.7 \pm 1.21^{\mathrm{c}}$ & $1935.2 \pm 5.68^{\mathrm{b}}$ & $10.8 \pm 0.94^{\mathrm{a}}$ & $6.98 \pm 0.52^{\mathrm{a}}$ \\
$20 \mathrm{KRC}$ & $5.18 \pm 0.12^{\mathrm{a}}$ & $18.3 \pm 0.94^{\mathrm{b}}$ & $17.6 \pm 1.66^{\mathrm{a}}$ & $2275.2 \pm 4.21^{\mathrm{a}}$ & $11.2 \pm 1.32^{\mathrm{a}}$ & $6.66 \pm 0.94^{\mathrm{a}}$ \\
$40 \mathrm{KRC}$ & $4.96 \pm 0.35^{\mathrm{ab}}$ & $19.1 \pm 1.74^{\mathrm{b}}$ & $14.3 \pm 0.87^{\mathrm{b}}$ & $2235.3 \pm 6.67^{\mathrm{a}}$ & $11.2 \pm 0.17^{\mathrm{a}}$ & $5.01 \pm 0.86^{\mathrm{b}}$ \\
60KRC & $5.64 \pm 0.17^{\mathrm{a}}$ & $22.2 \pm 1.09^{\mathrm{a}}$ & $10.1 \pm 0.22^{\mathrm{d}}$ & $1636.5 \pm 3.54^{\mathrm{c}}$ & $11.4 \pm 1.10^{\mathrm{a}}$ & $4.28 \pm 0.72^{\mathrm{c}}$ \\
ANOVA & $*$ & $*$ & $*$ & $* *$ & NS & $*$ \\
One Way & & $*$ & $*$ & & \\
\hline
\end{tabular}

Means within a column followed by same letter are not significantly different $(\mathrm{P} \leq 0.05)$. The data shown are mean $\pm \mathrm{SE}$ of four replicates. Different letters a, $\mathrm{b}$, $\mathrm{c}$ and $\mathrm{d}$ denote significant difference $(\mathrm{p} \leq 0.05)$ between the treatments.

*Statistically significant difference at $\mathrm{P} \leq 0.05$

** Statistically significant difference at $\mathrm{P} \leq 0 . .001$

The results doesn't show any significant increase in the average shoot and root length per plant in M1 generation, however a slight enhancement in the shoot length was recorded by the seedlings subjected to $60 \mathrm{KRC}$ gamma 
irradiation dose but it was not significant (Table 1). The average number of leaves and leaf area per plant (Table 1) was stimulated significantly by $20 \mathrm{KRC} \quad(17.6 \pm 1.66$, $2275.2 \pm 4.21)$ in comparision to the control (12.4 \pm 0.44 , 1975.1 \pm 3.56$)$ The $60 \mathrm{KRC}$ dose inhibited the leaf formation and reduced the average leaf area significantly $(P \leq 0.05)$ than the control set. The highest number of branches per plant were formed under $10 \mathrm{KRC}$ treatment $(6.98 \pm 0.52)$, followed by $20 \mathrm{KRC}(6.66 \pm 0.94)$ than the control $(5.31 \pm 0.37)$.

Different growth parameters showed a significant difference under different treatments, when the plants were observed upto M2 generation (Table 2). The results confirm that the gamma irradiations can be better tool in modifying the different growth parameters upto number of generations. In M2 generation a significant enhancement in average root and shoot length have been observed under the 40KRC $(8.49 \pm 0.35,28.03 \pm 2.17)$ than under the control $(4.31 \pm 0.21$, $13.44 \pm 1.12)$. An overall two fold enhancement of these parameters was recorded in M2 generation. Average leaf length and leaf area also enhanced significantly across all treated seedlings. The highest numbers of leaves were formed in the plants treated at $40 \mathrm{KRC}$ and $60 \mathrm{KRC}$ dose level (Table 2 ), whereas the other treatment doesn't record any significant variation than the control. The average leaf area increased significantly in M2 generation, gaining the maximum value in the seedling treated with $10 \mathrm{KRC}(5875.41 \pm 11.42)$ than the control (0729.12 \pm 06.58$)$. Results obtained for the average number of branches per plant in M2 generation doesn't alter than the results obtained in M1 generation.

Table 2. Average root length, Shoot length, number of leaves, leaf length and number of branches per plant in Amaranthus caudatus under influence of different doses of gamma radiations (M2 generation) after 105 days of sowing.

\begin{tabular}{|c|c|c|c|c|c|c|}
\hline Dose & $\begin{array}{l}\text { Average Root } \\
\text { Length/plant (cm) }\end{array}$ & $\begin{array}{l}\text { Average Shoot } \\
\text { Length/plant }(\mathrm{cm})\end{array}$ & $\begin{array}{l}\text { Average No. of } \\
\text { Leaves/plant }\end{array}$ & $\begin{array}{l}\text { Average Leaf Area } \\
\text { /plant }\left(\mathrm{cm}^{2}\right)\end{array}$ & $\begin{array}{l}\text { Average Leaf } \\
\text { length /plant }(\mathrm{cm})\end{array}$ & $\begin{array}{l}\text { Average number of } \\
\text { branches }\end{array}$ \\
\hline Control & $4.31 \pm 0.21^{\mathrm{c}}$ & $13.44 \pm 1.12^{\mathrm{c}}$ & $09.20 \pm 0.98^{\mathrm{b}}$ & $0729.12 \pm 06.58^{\mathrm{e}}$ & $13.20 \pm 0.64^{\mathrm{c}}$ & $4.20 \pm 0.24^{\mathrm{c}}$ \\
\hline $10 \mathrm{KRC}$ & $5.67 \pm 0.46^{\mathrm{bc}}$ & $12.40 \pm 0.94^{\mathrm{c}}$ & $09.30 \pm 0.42^{\mathrm{b}}$ & $5875.41 \pm 11.42^{\mathrm{a}}$ & $17.30 \pm 1.21^{\mathrm{a}}$ & $6.10 \pm 0.46^{\mathrm{a}}$ \\
\hline 20KRC & $4.97 \pm 0.12^{\mathrm{c}}$ & $11.14 \pm 0.52^{\mathrm{c}}$ & $09.40 \pm 1.02^{\mathrm{b}}$ & $2912.35 \pm 09.32^{\mathrm{c}}$ & $12.20 \pm 0.69^{c}$ & $6.20 \pm 0.21^{\mathrm{a}}$ \\
\hline $40 \mathrm{KRC}$ & $8.49 \pm 0.35^{\mathrm{a}}$ & $28.03 \pm 2.17^{\mathrm{a}}$ & $11.05 \pm 0.69^{\mathrm{c}}$ & $3917.18 \pm 06.64^{\mathrm{b}}$ & $13.40 \pm 0.32^{\mathrm{c}}$ & $5.10 \pm 0.30^{\mathrm{bc}}$ \\
\hline $60 \mathrm{KRC}$ & $6.62 \pm 0.17^{b}$ & $16.04 \pm 1.66^{\mathrm{b}}$ & $11.60 \pm 1.32^{\mathrm{c}}$ & $2775.12 \pm 08.74^{\mathrm{d}}$ & $15.17 \pm 0.94^{\mathrm{b}}$ & $5.00 \pm 0.25^{\mathrm{bc}}$ \\
\hline $\begin{array}{l}\text { ANOVA } \\
\text { One Way }\end{array}$ & $*$ & * & $*$ & $* *$ & $*$ & $*$ \\
\hline
\end{tabular}

Means within a column followed by same letter are not significantly different $(\mathrm{P} \leq 0.05)$. The data shown are mean $\pm \mathrm{SE}$ of four replicates. Different letters a, $\mathrm{b}$ $\mathrm{c}$ and d denote significant difference $(\mathrm{p} \leq 0.05)$ between the treatments.

* Statistically significant difference at $\mathrm{P}<0.05$

** Statistically significant difference at $\mathrm{P}<0.001$

\section{Discussion}

With the help varied irradiation treatments productivity in Amaranthus caudatus can be increased. With rapid change in climate at global level, which influences productivity of crops, gamma rays can be handy for higher productivity [21] of plants. As the exposure of gamma irradiations is known to produce morphological, physiological and biochemical mutants. These improved mutants have the properties with high production of metabolites, and high productivity [2224]. In the present study the the gamma irradiations were tested to modify the germination, growth and yield of Amaranthus caudatus. The results of the present study showed that gamma rays is an efficient tool for increasing growth and yield in Amaranthus caudatus. It was observed that there were significant effect on the plant development and production in the M1 and M2 generation.

The plant height variation under different irradiation treatments were observed in comparision to the control in M1 generation. This is in accordance with report [25-27] in soybean, observed that the exposure of gamma irradiation influence the plant height moderately. However in M2 generation it was observed that the plant height was significantly altered. The reports [28] in pigeon pea and in sorghum [29] showed enhancement effect in the plant height in M2 generation. They observed that plant height increased with the application of gamma irradiation under the treatment of $40 \mathrm{KRC}$ and $60 \mathrm{KRC}$. The stimulating effect of gamma irradiation on plant height may be due to stimulation of cell division or cell elongation, due to alteration of metabolic processes which affect synthesis of phytohormones and nucleic acids [30]. It was noted in present study that the gamma irradiations stimulate the root growth in both M1 and M2 generations. It was observed that gamma irradiations significantly increase the root growth in Canscora decurrens [31]. a stimulatory influence of gamma irradiations on root growth of Terminalia tomentosa [32]. The data in table 1 shows the maximum number of branches $(6.98 \pm 0.52)$ per plant were found under $10 \mathrm{KRC}$ and it was followed by 20 KRC (6.66 \pm 0.94$)$ than the control $(5.31 \pm 0.37)$. The minimum value for number of branches/plant was noticed under $60 \mathrm{KRC}$ treatment $(4.28 \pm 0.72)$. The stimulation in number of branches by lower doses of gamma irradiations and reduction in number of branches by higher doses of gamma irradiations in Brassica napus was noted [26]. The increased branches and leaves may be due to the enhanced production of IAA and kinetin which stimulates the production of large number of leaves and branches [33].

The results obtained in the present study (Table 2) indicates that there is a significant differences in the yield per plant in Amaranthus caudatus for M1 and M2 generations. The stimulation in the yield might be directly related to the 
gene compliment, which might have been activated by the exposure of gamma treatments [34]. As, the similar results in the present study were seen in M2 generation thus the foresaid explanation (activation of genes) can be better confirmed. a significant increase of chickpea grain yield using gamma irradiation at 600 Gy was reported [29]. High yielding and early maturing barley plants were developed by mutation breeding methods [35]. Highest grain yield increase in soybean irradiated with $20 \mathrm{KR}$ of gamma rays was reported [27]. The increase in the grain yield can also be correlated with the increase in the average leaf area per plant by $20 \mathrm{KRC}$ and 40KRC treatments, which potentially increased the growth rate and hence stimulating the average grain yield of Amaranthus caudatus. The increase in the grain yield by the application of gamma irradiation treatments can be exploited for the commercial cultivation of treated Amaranthus caudatus crop to fulfill the gap existing in the food security problems of the country.

\section{Conclusion}

According to the obtained results, it was concluded that the gamma irradiation treatments significantly alter the different morpho-agronomic traits in Amaranthus caudatus. The effects of $20 \mathrm{KRC}$ and $40 \mathrm{KRC}$ irradiation treatments were recognized as radiopotential doses, as these treatments significantly increased the average grain yield per plant upto M2 populations. The selection of the treated plants with specific dose with a specific morpho-agronomic trait, can be preferred for the cultivation of Amaranthus caudatus at commercial base, in terms of the concerns over food security.

\section{References}

[1] Saunders RM and Becker R. 1984. Amaranthus: A potential food and feed resource. Page 357 in: Advances in Cereal Science Technology, Vol 5. Y. Pomeranz, ed. Am. Assoc. Cereal Chem.: St. Paul, MN.

[2] Garuda AM. 2004. Amaranth grain, garuda international. Retrieved from Garuda International.www.garudaint.com/product.php.

[3] Fan J, Shi M, Huang JZ, Xu J, Wang ZD and Guo DP. 2014. Regulation of photosynthetic performance and antioxidant capacity by ${ }^{60} \mathrm{Co} \gamma$-irradiation in Zizania latifolia plants. Journal of Environmental Radioactivity, 129: 33-42.

[4] Esnault MA, Legue F and Chenal C. 2010. Ionizing radiation: advances in plant response. Environmental and Experimental Botany, 68: 231-237.

[5] Shabana EF, Gabr MA, Moussa HR, El-Shaer EA and Ismaiel MMS. 2016. Biochemical composition and antioxidant activities of Arthrospira (Spirulina) platensis in response to gamma irradiation. Food Chemistry, 214: 550-555.

[6] Kovacs E and Keresztes A. 2002. Effect of gamma and UV$\mathrm{B} / \mathrm{C}$ radiation on plant cell. Micron, 33: 199-210.

[7] Sparrow AH, Sparrow RC, Thompson KH and Schairer LA. 1965. The use of nuclear and chromosomal variables in determining and predicting radiosensitivities. Radiation Botany (Suppl.) 5, 101-132.

[8] Sparrow AH and Woodwell GM. 1962. Pre- diction of the sensitivity of plants to chronic gamma irradiation. Radiation Botany, 2: 9- 26.

[9] Kim JH, Baek MH, Chung BY, Wi SG and Kim JS. 2004. Alterations in the photosynthetic pigments and antioxidant machineries of red pepper (Capsicum annuum L.) Seedlings from gamma irradiated seeds. Journal of Plant Biology, 47: 314-321.

[10] Wi SG, Chung BY, Kim JH, Baek MH, Yang DH, Lee JW and Kim JS. 2005. Ultrastructural changes of cell organelles in Arabidopsis stem after gamma irradiation. J. Plant Biol, 48 (2): 195-200.

[11] Jia CF, Li AL. (2008). Effect of gamma radiation on mutant induction of Fagopyrum dibotrys Hara. Photosynthetica, 46: 363-369.

[12] Kim SH, Song M, Lee KJ, Hwang SG, Jang CS, Kim JB, Kim, SH, Ha BK, Kang SY and Kim DS. (2012). Genomewide transcriptome profiling of ROS scavenging and signal transduction pathways in rice (Oryza sativa L.) in response to different types of ionizing radiation. Molecular Biology Reports, 39: 11231-11248.

[13] Pereira Eliana, Barros Lillian, Barreira J. C. M., Carvalho Ana Maria, Antonio Amilcar L. and Ferreira ICFR. 2016. Electron beam and gamma irradiation as feasible conservation technologies for wild Arenaria montana L.: Effects on chemical and antioxidant parameters. Innovative Food Science and Emerging Technologies, 36: 269-276.

[14] Marcu D, Cristea V and Darban L. 2013. Dose-dependent effects of gamma radiation on lettuce (Lactuca sativa var. capitata) seedlings. Int J Radiat Biol 89: 219-223.

[15] Majeed A and Muhammad Z. 2010. Gamma irradiation effects on some growth parameters of Lepidium sativum L. World J Fungal Plant Biol 1 (1): 8-11.

[16] Singh SS and Sujata. 2004. Effect of gamma rays on seed germination and seedling growth of Robinia pseudoacacia. Indian Journal of Agroforestry, 6 (1): 33-38.

[17] Singh SS and Vandana. 2008. Sensitivity of Albizia julibrissin Durazz Seeds to Gamma Rays. In proceeding of the FORTROP II: Tropical Forestry Change in a Changing World, 17-20 November 2008, Kasetsart University, Bangkok, Thailand, 25-39.

[18] Mackay WA, Davis TD and Sankhla D. 1995. Influence of scarification and temperature treatments on seed germination of Lupinus havardii. Seed Science \& Technology, 23: 815821.

[19] Czabator FJ. 1962. Germination value: an index combining speed and completeness of Pine seed germination. Forest Science, 8: 386-396.

[20] Duncan DB. 1955. Multiple range and multiple $F$ tests. Biometrics, 11: 1-42.

[21] Jan Sumira, Parween Talat, Siddiqi TO and Mahmooduzzafar. 2012. Effect of gamma radiation on morphological, biochemical, and physiological aspects of plants and plant products. Environment Reviews, 20: 17-39. 
[22] Sato Y, Shirasawa K, Takahashi Y, Nishimura M, Nishio T (2006) Mutant selection from progeny of gamma-rayirradiated rice by DNA heteroduplex cleavage using Brassica petiole extract. Breed Sci 56: 179-183.

[23] Eroglu Y, Eroglu HE and Ilbas AI. 2007. Gamma ray reduces mitotic index in embryonic roots of Hordeum vulgare L. Adv Biol Res 1 (1-2): 26-28.

[24] Sansenya Sompong, Hua Yanling, Chumanee Saowapa, Phasa Kannika and Sricheewin Chanun. 2017. Effect of Gamma Irradiation on 2-Acetyl-1-pyrroline Content, GABA Content and Volatile Compounds of Germinated Rice (Thai Upland Rice). Plants, 6 (18): 3-12.

[25] Shakoor A, Haq MA and Sadiq M. 1978. Induced Genetic Variability in M2 and Evaluation of Promising Mutant Lines in M4 Generation of Mung Bean," Pakistan Journal of Agricultural Science, 5 (1-2): 1- 6 .

[26] Khan Wisal Muhammad, Shah Syed Zahir, Khan Muhammad Saleem, Zia Ul Islam, Ali Sajjad, Hussain Fida, Irshad Muhammad and Muhammad Zahid. (2014). Effects of gamma radiations on some morphological and biochemical characteristics of Brassica napus L. (variety Altex). International Journal of Biosciences. 4 (10): 36-41.

[27] Mudibu J, Nkongolo KK, Kalonji-Mbuyi A and Kizungu R. 2010. Effect of Gamma Irradiation on Morpho-Agronomic Characteristics of Soybeans (Glycine max L.)," American Journal of Plant Science 3 (3): 331-337.

[28] Rao S K. 1988. Gamma Ray Induced Morphological and Physiological Variations in Cicer arietinum L.," Indian Journal of Botany, 11 (1): 29-32.
[29] Khan MR, Qureshi AS, Hussain SA and Ibrahim M. 2005. Genetic Variability Induced by gamma irradiation and Its Modulation with Gibberellic Acid in M2 Generation of Chickpea (Cicer arietinum L.)," Pakistan Journal of Botany, 37 (2): 285-292.

[30] Pitirmovae MA (1979) Effect of gamma rays and mutagens on barley seeds. Physiological Research 6: 127-131.

[31] Yadav V. 2016. Effect of gamma radiation on various growth parameters and biomass of Canscora decurrens Dalz. International Journal of Herbal Medicine, 4 (5): 109-115.

[32] Singh S S and Wani Mohd Rafi. 2017. Sensitivity and potential of Terminalia tomentosa Roxb towards different gamma irradiation exposure regimes at early growth phases. International Journal of Science and Research (IJSR). 6 (1): $2409-2418$

[33] Minisi FA, El-mahrouk ME, Rida MEF and Nasr MN. 2013. Effects of gamma radiation on germination, growth characteristics and morphological variations of Moluccella laevis L. Am-Euras. J. Agric. Environ. Sci. 13 (5): 696-704.

[34] Gay F, Maraval I, Roque S, Gunata Z, Boulanger R, Audebert $A$ and Mestres C. 2010. Effect of salinity on yield and 2acetyl-1-pyrroline content in the grains of three fragrant rice cultivars (Oryza sativa L.) in Camargue (France). Field Crops Res. 117: 154-160.

[35] Gustafsson A, Hagberg A, Persson G and Wikland K. 1971. Induced mutation and barley improvement. Theoretical Appl. Gene. 41: 239-48. 